\title{
イヌ精子の代謝に関する研究
}

\section{II. 緩衝液および希釈液の影響について}

\author{
黒田治門・広 江一正 \\ （宮崎大学農学部・家畜生理学教室）
}

\section{はじめに}

家畜精子の保存に関して, 各種の緩衝液や希釈液が報 告されているが，家畜の種類によりその組成がかなり異 なっている。これは精子の生存に必要な至適条件が種類 によって異なり，代謝能に関しても種類による特異性の あることを示すものである。イマ精子の保存液に関する

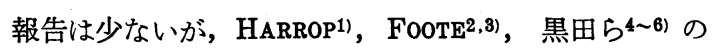
報告している希釈液はいずれも良好な保存成績を示して おり，人工授精に成功しているものもある ${ }^{1,6)}$ 。また， イヌ精子の代謝に関しては IVANOV7), MANN ${ }^{8,9)}$, BARTLETT $^{10)}$, WALES ${ }^{11)}$, MURDOCH ${ }^{12)}$, 黑田ら ${ }^{13) な と ゙ の ~}$ 報告があり，そのイオン組成，基質の種類，季節などに よって呼吸能および解糖能に差のあることが報告されて いる。しかし, 他の家畜精子にくらべて報告が少なく, 解明さるべき点が多いといわざるをえない。

そこで本実験では, 各種の緩衝液および希釈液がイ 精子の生存性ならびに代謝能におよ汸す影響を明らかに しょうとした。

\section{実験材料および方法}

供試動物にはスピッツ種の成雄犬（2４才） 10 頭を 用いた。精液は手指法で分画採取し，実験には 2 nd fraction を用いた。実験は原精液と精子を各希釈液で 1 回洗浄（2,000 r.p.m., 10 分遠沈一上清除去）した のち，それぞれの希釈液を加えて 2 倍に希釈した希釈精 液について行なった。供試精液は秋に採取したものを用 いた。

測定項目は温浴前後の精子生存率, 呼吸量, 糖消費量

Studies on the metabolism of dog spermatozoa. II. Effects of buffers and diluents on the aerobic metabolism of dog spermatozoa.

KURODA, Haruto \& Kazumasa, HIRoE (Department of Veterinary Physiology, University of Miyazaki, Miyazaki, 880)

Jap. J. Animal Reporod. 19 (3), 1973.
および乳酸蓄積量であった。

精子の生存率および活力は精子生存指数に換算してカ ッコ内に示した。

呼吸量はワールブルグ検圧装置を用いて， $37^{\circ} \mathrm{C} て ゙ 2$ 時間好気的条件下で測定し， 1 時間値および 2 時間值を 生存精子 1 億当りの $\mu l$ で示した。

糖消費量は温浴直前に基質としてグルコースまたはフ ラクトースをそれぞれ $1.2 \sim 1.4 \mathrm{mg} / \mathrm{ml}$ ずつ供試精液 に添加し, 前後の糖質含量の差を求め, 2 時間の糖消費 量を生存精子 1 億当りの $\mu \mathrm{g}$ として示した。糖質の測定 はグルコースについては SoMOGYI 法14)，フラクトース については ROE の方法 ${ }^{15}$ によって比色定量した。

乳酸蓄積量は温浴の前後における供試精液の乳酸含量 を BARKER \& SUMMERSON の方法(6)により比色定量し， その差をもって乳酸蓄積量とした。成績は 2 時間の乳酸 蓄積量を生存精子 1 億当りの $\mu \mathrm{g}$ で示した。

なお，原精液に打ける測定值と比較するために，希釈 液に関するそれぞれの湘定值を原精液の場合の数值で除 して，えられた数值に 100 を乗じた值を指数としてカッ コ内に示した。

供試した希釈液および緩衝液の組成はつぎの通りであ る。

a) $\mathrm{Ca}$ 欠 KRP 液 17

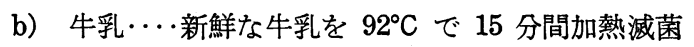
する

c）グリシン液 (3\%)

d) 食塩液 $(0.9 \%)$

e）第 2 リン酸ナトリウム液 $(0.1 \mathrm{M})$

f）グルタミン酸ナトリウム液 $(3.8 \%)$

g) ペプトン添加緩衝液 ( $\mathrm{mg} \%)$

$\begin{array}{lrlr}\mathrm{Na}_{2} \mathrm{HPO}_{4} \cdot 12 \mathrm{H}_{2} \mathrm{O} & 40, & \mathrm{KCl} & 60 \\ \text { Glycine } & 750, & \text { Peptone } & 1,000 \\ \mathrm{Na}_{2} \mathrm{C}_{6} \mathrm{H}_{5} \mathrm{O}_{7} \cdot 2 \mathrm{H}_{2} \mathrm{O} & 1,800 & & \end{array}$

h) PETIC 液5) ( $\mathrm{mg} \%)$

$\mathrm{Na}_{2} \mathrm{HPO}_{4} \cdot 12 \mathrm{H}_{2} \mathrm{O} \quad 20, \quad \mathrm{KCl} \quad 30$


Table 1. Effects of buffers and diluents on the aerobic glycolysis of dog spermatozoa $(n=9 \sim 4)$

\begin{tabular}{|c|c|c|c|c|c|c|}
\hline \multirow[t]{2}{*}{ Diluent } & \multicolumn{2}{|c|}{$\operatorname{Sperm}_{(\%)}$ viability } & \multicolumn{2}{|c|}{$\begin{array}{cl}\mathrm{O}_{2} & \text { uptake } \\
\left(\mu l / 10^{8} \text { live sperm }\right)\end{array}$} & \multirow{2}{*}{$\begin{array}{l}\text { Glucose utilized } \\
\left(\begin{array}{c}\mu \mathrm{g} / 10^{8} \text { live } \\
\text { sperm } / 2 \mathrm{hrs}\end{array}\right)\end{array}$} & \multirow{2}{*}{$\begin{array}{l}\text { Lactate } \\
\text { accumulated } \\
\left(\begin{array}{c}\mu \mathrm{g} / 10^{8} \text { live } \\
\text { sperm } / 2 \mathrm{hrs}\end{array}\right)\end{array}$} \\
\hline & Initial & Final & $1 \mathrm{hr}$ & $2 \mathrm{hrs}$ & & \\
\hline Control (intact semen) & 94 & $57(20) *$ & 12.2 & $20.8(100)$ & $139(100)$ & $206(100)$ \\
\hline Ca free-KRP & 95 & $62(32)$ & 9.1 & $16.3(78)$ & $122(87)$ & $29(15)$ \\
\hline Milk & 95 & $42(13)$ & 25.1 & $52.8(253)$ & $279(200)$ & $825(400)$ \\
\hline Glycine & 95 & $15(3)$ & 15.6 & $23.3(112)$ & $142(102)$ & 21 ( 19$)$ \\
\hline Sodium chloride & 94 & $55(33)$ & 12.9 & $20.8(100)$ & $183(132)$ & $415(201)$ \\
\hline Phosphate buffer & 95 & $31(9)$ & 24.1 & $28.6(137)$ & $145(104)$ & $142(69)$ \\
\hline Sodium glutamate & 93 & $80(55)$ & 14.6 & $25.3(121)$ & 163 (117) & $346(168)$ \\
\hline Peptone buffer & 92 & $58(43)$ & 10.6 & $22.1(106)$ & $64(46)$ & $118(57)$ \\
\hline PETIC solution & 94 & $74(50)$ & 11.6 & $22.1(106)$ & $209(150)$ & 326 (158) \\
\hline
\end{tabular}

( )* Motility index of sperm

Table 2. Effects of buffers and diluents on the aerobic fructolysis of dog spermatozoa $(n=9 \sim 4)$

\begin{tabular}{|c|c|c|c|c|c|c|}
\hline \multirow{2}{*}{ Diluence } & \multicolumn{2}{|c|}{$\begin{array}{c}\text { Sperm viability } \\
(\%)\end{array}$} & \multicolumn{2}{|c|}{$\begin{array}{c}\mathrm{O}_{2} \text { uptake } \\
\left(\mu l / 10^{8} \text { live sperm }\right)\end{array}$} & \multirow{2}{*}{$\begin{array}{l}\text { Fructose utilized } \\
\left(\begin{array}{c}\mu \mathrm{g} / 10^{8} \text { live } \\
\text { sperm } / 2 \mathrm{hrs}\end{array}\right)\end{array}$} & \multirow{2}{*}{$\begin{array}{l}\text { Lactate } \\
\text { accumulated } \\
\left(\begin{array}{c}\mu \mathrm{g} / 10^{8} \text { live } \\
\text { sperm } / 2 \mathrm{hrs}\end{array}\right)\end{array}$} \\
\hline & Initial & Final & $1 \mathrm{hr}$ & $2 \mathrm{hrs}$ & & \\
\hline Control (intact semen) & 95 & $48(17) *$ & 11.5 & $18.9(100)$ & $170(100)$ & $235(100)$ \\
\hline Ca free-KRP & 92 & $52(10)$ & 13.9 & $23.4(124)$ & $268(156)$ & $129(55)$ \\
\hline Milk & 95 & $50(10)$ & 24.0 & $42.3(224)$ & $210(123)$ & $499(212)$ \\
\hline Glycine & 95 & $51(6)$ & 12.2 & 21.7 (114) & $198(116)$ & $55(23)$ \\
\hline Sodium chloride & 95 & $62(33)$ & 11.0 & $17.4(92)$ & 231 (136) & $94(40)$ \\
\hline Phosphate buffer & 95 & $20(5)$ & 45.6 & $47.3(250)$ & 233 (137) & $53(23)$ \\
\hline Sodium glutamate & 93 & $73(40)$ & 11.8 & $23.2(123)$ & $216(127)$ & 269 (114) \\
\hline Peptone buffer & 95 & $60(40)$ & 12.5 & $22.7(120)$ & $438(258)$ & $29(12)$ \\
\hline PETIC solution & 95 & $81(60)$ & 18.8 & $38.3(203)$ & $53(31)$ & $568(242)$ \\
\hline
\end{tabular}

( )* Motility index of sperm

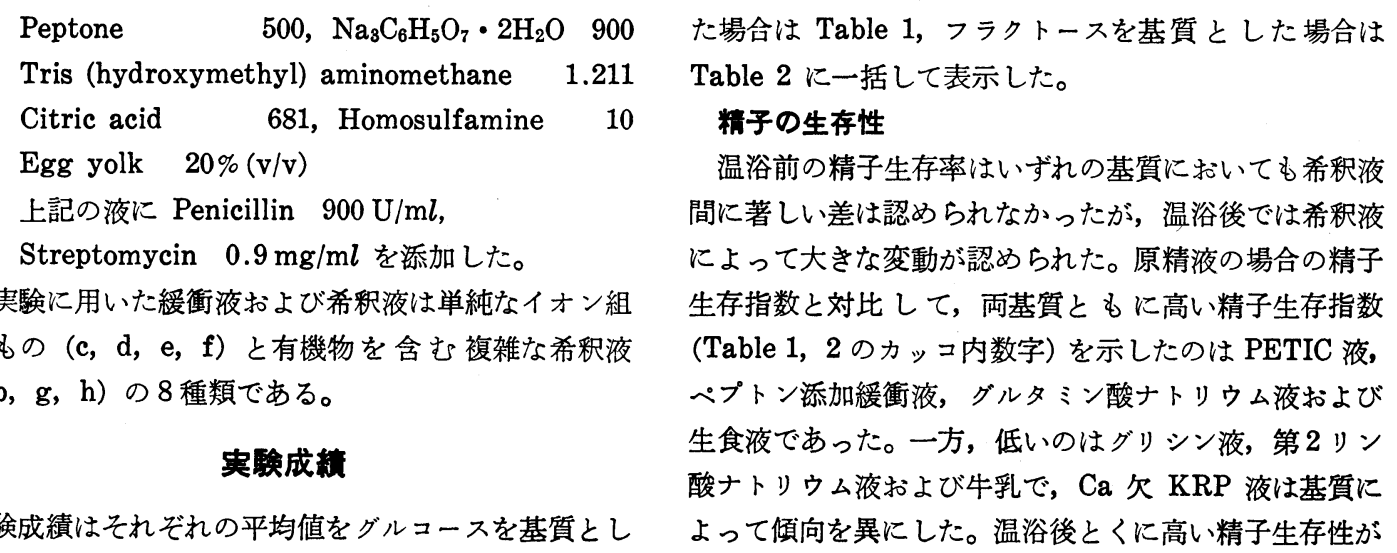


1973 年 12 月

示されたのは PETIC 液とグルタミン酸ナトリウム液で ある。

\section{呼吸是}

生存精子 1 億 2 時間当りの呼吸量を原精液の場合と対 比した指数 (Table 1, 2 のカッコ内数字) で比較する と,グルコースを基質とした場合は牛乳, 第 2 リン酸ナ トリウム液, グルタミン酸ナトリウム液およびグリシン 液が高く, Ca 欠 KRP 液では低下している。フラクト 一スを基質とした場合は生食液で低下した以外はすべて 増加している。両基質ともに呼吸量の増加を認めた希釈 液は牛乳と第 2 リン酸ナトリウム液である。とくに牛乳 では原精液の 2 倍以上の呼吸量を示し, 第 2 リン酸ナト リウム液では初めの 1 時間で全呼吸量の約 $90 \%$ が消費 され，その後急速に低下することが示されたことは注目 すべきことである。PETIC 液ではグルコースの場合は 著しい増加を示さなかったのに対して，フラクトースで は約 2 倍に増加している。

\section{糖消霓量}

両基質ともに高い指数を示した希釈液は牛乳，グリシ ン液, 生食液, 第 2 リン酸ナトリウム液およびグルタミ ン酸ナトリウム液で，他の希釈液は基質によって傾向を 異にしている。すなわち, Ca 欠 $\mathrm{KRP}$ 液およびペプト ン添加緩衝液はグルコースでは低下し，フラクトースで は増加している。とくに後者においてはこの傾向が著し いといえる。PETIC 液ではグルコースの消費量が多く, フラクトースの消費量は著しく減少している。

\section{乳酸蓄積量}

原精液の場合と指数で比較すると, 両基質ともに高い のは牛乳, PETIC 液およびグルタミン酸ナトリウム液 で，その他の希釈液ではいずれも低下している。とくに グリシン液および第 2 リン酸ナトリウム液では著しく低 值を示したことは注目すべきことである。

希釈液別にみた精子の生存性および代謝能は，つぎの とおりである。

a） $\mathrm{Ca}$ 欠 $\mathrm{KRP}$ 液：総体的にフラクトースの場合に 代謝能が高い。前報の成績（洗浄精子の代謝）にくらべ て原精液に対する相対的な比率は低いが，各項目の測定 值はほぼ一致している。

b) 牛乳: 呼吸量, 糖消費量および乳酸蓄積量とも に著しく高い值を示し, イヌ精子の代謝能を促進する効 果のあることが示された。しかし, 温浴後の精子生存率 はかなり低下している。

c）グリシン液：呼吸量および 糖消費量は原精液の 場合とほぼ同じか, やや増加する結果が得られたにもか
家畜繁殖誌 19 巻 3 号

かわらず，乳酸蓄積量は両基質ともに対照の約 $20 \%$ で 著しい低下を示した。温浴後の精子生存率はきわめて低 い。

d）生食液：糖消費量は基質を問わず約 $30 \%$ 増加し ているにもかかわらず，乳酸蓄積量はグルコースで約 2 倍，フラクトースでは半減と全く逆の傾向が示された。 精子生存率および呼吸能などはほぼ一定の值を示してい ることを考慮すると, 生食液では精子の乳酸分解能は基 質による差が著しいものと推測される。

e）第 2 リン酸ナトリウム液：呼吸量が著明な増加 を示し，しかも全呼吸量（2時間）の約 $85 \%$ 以上が最 初の 1 時間に消費され, 以後急速に低下するという特異 な傾向が示された。この傾向は他の希釈液には認められ なかった。糖消費量はフラクトースにおいて対照よりも 約 $30 \%$ 多い。乳酸蓄積量および温浴後の精子生存率は 両基質ともに低値を示した。

f）グルタミン酸ナトリウム液：精子生存率および 代謝能ともに原精液より高い值が示された。

g） ペプトン添加緩衝液：呼吸量は原精液の場合之 ほぼ等しいが，糖消費量はグルコースで半減し，フラク トースでは約 2.5 倍の高い値を示して全く逆の傾向が示 された。これに対して乳酸蓄積量はいずれの基質でも低 い値を示した。温浴後の精子生存率はかなり高い。

h） PETIC 液：温浴後の精子生存性は供試希釈液の 中では最もよいといえる。呼吸量はグルコースではほぼ 原精液と一致しているが，フラクトースでは約 2 倍に増 加している。糖消費量はグルコースで高く，フラクトー スでは減少して呼吸量とは逆の傾向が認められた。乳酸 蓄積量はいずれの基質でも増加している。これらの傾向 はペプトン添加緩衝液とはほぼ逆の関係にあるといえ る。

\section{考察}

豚精子に関する瑞穂ら ${ }^{18)}$ の成績では，原精液にくらべ て, 呼吸量については牛乳, 卵黄りン酸緩衝液および卵 黄クエン酸液（以下卵ク夜と略記）で希釈した場合に高 く，フラクトース消費量と乳酸蓄積量については牛乳系 統の希釈液では高いが, 卵黄リン酸緩衝液, 卵ク液, グ リシン液, グルタミン酸ナトリウム液, $\mathrm{Ca}$ 欠 KRP 液, 生食液およびリン酸緩衝液ではすべて低い值を示してい る。とくに, グルタミン酸ナトリウム液, 卵黄リン酸緩衝 液およびグリシン液では糖消費量と乳酸蓄積量は半減し ている。これらの成績とイヌ精子の成績をくらべると, 牛乳では増加の傾向が一致しているが，他の希釈液につ 
1973 年 12 月

いては大きな差が認められる。また単一組成の希釈液 (c, d, e, f) 飞执ける精子の呼吸量之糖消費量はほぼ 增加の傾向を一にしているが，乳酸蓄積量は傾向を異に している。

グリシンは精子の生存に有効であり, PETIC 液の一 組成になっている。牛精子の代謝能におよぼすグリシン の影響について FLIPSE ら ${ }^{191} は$ ，フラクトース消費量は 減少しないが，乳酸蓄積量が減少することを明らかにし ている。イヌ精子に批る著者らの成績でも同様の傾向 が示された。DIETZ \& FLIPSE20) はグリシン-14C を用い て，グリシンが精子のグルコース利用を減少させる原因 を究明し, 精子内へのグリシンの取込みは active transport systemによること，このことは温度や阻害剂に 鋭敏に反応し,グルタミン酸, グルコース, アルギニン およびプロリンの間に競合が起こることを明らかにして いる。イヌ精子の場合にも同様の傾向が認められたこと から，グリシン代謝の方向性が暗示される。WALES \& WALLACE ${ }^{21)}$ は, 好気的条件下でのイヌ洗浄精子は, 乳 酸とフラクトースが共存する場合はフラクトースの酸化 率が高いこと, また, リン酸塩は牛精子の呼吸量の低下 ならびにフラクトース分解能の促進をもたらすが，その 他の家畜精子（イヌ，鬼，鷄）には呼吸を促進する以外 に他の代謝促進効果はないとのべている。本実験成績に おいても，グルタミン酸ナトリウム液以外の単一組成の 希釈液（c，d，e）ではほぼ一致する結果を示した。

グルタミン酸ナトリウム液では原精液よりもやや高い 代謝能を示し, 測定後の精子生存性む良好であったこと などから，イヌ精子の希釈液またはイヌ精子を処理する 場合の緩衝液に使用できると考兄られる。しかし，グル タミン酸ナトリウムがイ 又精子の代謝促進効果をむたら 寸理由は明らかでないが，代謝系路に何らかの役割を持 つことが推測され，今後明らかにされなければならな い。

牛乳をイ邓精子の希釈液として利用しらる1〕とが報 告されているが，代謝能におよぼす影響については論じ られていない。牛乳は供試希釈液 8 種類中もっとも著し い代謝促進効果を示したが，逆に精子の生存性の低下は 著しかった。また基質を添加しない場合でも原精液の場 合の約 2 倍の值を示したことなどから，牛乳中の各種の イオン，糖質および酵素などが相互に作用して代謝を促 進したものと考えられる。著者らの牛乳によるイヌ精子 の保存試験では長期保存効果が低かったが，その理由の 一つとして本実験で示された牛乳による精子の代謝促進 効果が考えられる。
家畜繁殖誌 19 巻 3 号

ペプトン添加緩衝液および PETIC 液においては, 精 子の生存性ならびに呼吸能は原精液よりも高い值を示し ているが，糖消費量と乳酸蓄積量との間には基質による 傾向の相違が明らかである。黒田ら ${ }^{13)}$ はイ 又精子の代謝 能が季節によって差のあることを明らかにし，秋にはグ ルコースよりもフラクトースの代謝量が多いとのべてい る。本実験成績においても大部分の希釈液では傾向にお いて一致しているが，牛乳と PETIC 液では逆の傾向が 示された。妌田 ${ }^{22)}$ は, 山羊精子に卵黄を添加すると呼吸 能が促進されるが，その原因物質は主として卵黄中のグ ルコースであるとのべている。これだけでは PETIC 液 に批る代謝促進効果の説明には不十分であるが，一つ の示唆を与えるものと考㝋られる。

代謝能と精子の生存性との関係は希釈液によって傾向 を異にしているが，供試希釈液 8 種類の中で両者ともに 良好な成績がえられたのは PETIC 液とグルタミン酸ナ トリウム液である。保存精液を人工授精に用いる場合, 精子の生存性維持だけでなく, 雌性生殖器内におけるる諸 要因に対応しらる能力，すなわち代謝能を保持していな ければならない。これらの観点から， PETIC 液はイ 精子の保存効果が高いだけでなく，代謝能も高いことか ら，希釈保存液として十分利用しらるものと考元られ る。

\section{要 約}

スピッツ種の成雄犬を用いて，イヌ精子の糖代謝能に 及ぼす希釉液の影響について検討した。その結果はつぎ の通りである。

1. 原精液よりも希釈精液の方がいずれの場合にも高 い代謝能を示した。

2. グリシン液およびリン酸緩衝液では呼吸量および 糖消費量が高いにもかかわらず，乳酸蓄積量はきわめて 低值を示した。これらの希釈液ではイヌ精子は糖の利用 と並行して乳酸も利用しらると推測される。

3. 牛乳およびグルタミン酸ナトリウム液で希积され た精子の呼吸能および解桾能は原精液の場合よりも高か った。この傾向は牛乳において特に著明であった。

4. PETIC 液は精子の生存維持ならびに糖代謝能の いずれに関しても好影響をもたらすことが知られた。

(1973. 7.7 受付)

\section{文 献}

1) Harrop, A. E.: J. Amer. Vet. Med. Assoc., 129. 564, 1956. 
2) Fооте, R. H.: Amer. J. Vet. Res., 25, 32, 1964.

3) Foote, R.H. \& E.P. Leonard; Cornell Vet., 54, 78, 1964.

4）黒田（治）・西川（義）・入谷（明）：凍結研会報 (31), 3, 1970.

5) 黒田（治）・西川（義）・入谷 (明)：第 159 回日 本臨床獣医学会 (福岡) 講演一日獣誌： 23, 650 , 1970.

6)黒田（治）広江 (一)：第 183 回日本臨床獣医学 会 (岐阜) 講演, 1972.

7) Ivanov, E. E.: C. $R$. Soc. Biol., Paris, 102, $363,1929$.

8) Mann, T.: J. Agric. Sci., 38, 323, 1948.

9) MANN, T. \& I. G. WhiTE: Nature, Lond., 178, 142, 1956.

10) Bartlett, D. J.: J. Reprod. Fertil., 3, 190, 1962.

11) Wales, R. G.: J. Reprod. Fertil., 10, 369, 1965.

12) MURDoch, R. N. \& I. G. WhITE: J. Reprod. Fertil., 12, 271, 1966.
13）黒田（治) - 広江 (一)：家畜繁殖誌，17，89, 1972.

14) Somogyi, M.: J. Biol. Chem., 195, 19, 1952, (cit 藤井著, 生化学実験法 定量編, 南山堂, 1961)

15) RoE, J.H.: J. Biol. Chem., 107, 15, 1934. (cit. 吉川著, 臨床医化学 I 実験編, 共同医書, 1966,

16) Barker, S. B. \& W. H. Summerson: J. Biol. Chem., 138, 535, 1941. (cit. 吉川著, 臨床医化 学 I 実験編, 共同医書, 1966)

17) UMBREIT, W.W., R.H. BURRIS \&J.F. STAUFFER: Manometric techniques and tissue metabolism. Baugess, Minneapolis, 1949.

18）瑞穂 (当) - 丹羽 (太) - 副島 (明)：家畜繁殖誌, 9, 92, 1963.

19) Flipse, R. J. \& J. O. Almquist: J. Dairy Sci., 41, 1787, 1958,

20) Dietz, R.W. \& R.J. Flipes: J. Dairy Sci., 49, 85, 1966.

21) Wales, R. G. \& J. C. Wallace: J. Reprod Fertil., 8, 361, 1964.

22）枡田（博)：学位論文 (京都大学), 1969.

\section{Summary}

The effects of eight sorts of diluent were studied on the metabolic activity of dog spermatozoa using ten adult male Spitzdogs. Spermatozoa in the second fraction of ejaculate were washed once with the diluents and resuspended in them. The results are summarized as follows:

1. In general, the metabolic activity of dog spermatozoa suspended in the diluents was higher than that in undiluted semen. The accumulation of lactic acid varied markedly according to the diluents.

2. The glycine and phosphate buffer were effective in stimulating oxygen uptake and glucose or fructose utilization of dog spermatozoa. However, the lactate was accumulated very little in these buffers.

3. Cow's milk diluent stimulated metabolic activity of dog spermatozoa markedly. Sodium glutamate diluent was shown to have a similar effect.

4. PETIC solution was effective keeping viability and glycolytic activity of dog spermatozoa. 